\title{
Kim są dzieci, jak się uczą? - jakościowa analiza wywiadu z wychowawcami w żłobku
}

\begin{abstract}
Abstrakt
$\mathrm{W}$ artykule przedstawiono rezultaty wywiadu grupowego z wychowawcami w żłobku, podczas którego wypowiadali się oni na temat różnych istotnych dla nich kwestii, dotyczących relacji z dziećmi, starali się odkryć swoje osobiste na ten temat "teorie” (implicit theories). W analizie danych inspirowano się założeniami teorii ugruntowanej. Wypowiedzi wychowawców wpisują się w dużym stopniu w globalnie akceptowane tezy na temat wysokiej jakości oddziaływania instytucjonalnego, sprzyjającego rozwojowi dziecka.
\end{abstract}

Słowa kluczowe: wychowawcy, żłobek, teorie osobiste, teoria ugruntowana, kokonstrukcja znaczeń i sensów pracy z najmłodszymi dziećmi.

\section{Who are children, how do they learn? - Qualitative analysis of interview with caregivers in crèche}

\begin{abstract}
This article presents the results of a focus group interview with caregivers in a crèche, during which they spoke about various issues important to them concerning their relationships with children and they tried to discover their personal implicit theories and expectations on this subject. The analysis of the data was greatly inspired by the assumptions of the grounded theory. The statements provided by the caregivers fit in, to a large extent, the globally recognized ideas concerning the high quality ECEC impact on child's development.
\end{abstract}

Keywords: caregivers, crèche, implicit theory, grounded theory, co-constuction of meanings of pedagogical work with the youngest children.

\footnotetext{
* Uniwersytet Warszawski, Wydział Pedagogiczny.
} 


\section{Wstęp}

Rozważania zacznę od cytatu zaczerpniętego z tekstu Robina Aleksandra pt. Culture, dialogue and learning: notes on an emerging pedagogy:

Edukacja to nie jest zestaw technik, strategii działania, ale to interwencja kulturowa ukierunkowująca rozwój jednostki, głęboko zanurzona w systemie wartości, historii społeczeństwa i lokalnej wspólnoty, nauczając przekazujemy idee, wartości i kolektywną historię, które wspólnie kierują oddziaływaniem nauczyciela (Aleksander 2005: 1).

Autor formułuje tezy oczywiste dla większości akademików, nauczycieli, rodziców. Praca nauczyciela z dziećmi, niezależnie od poziomu edukacji, to skomplikowany proces interakcji, w który uwikłane są różnorodne czynniki psychologiczne, społeczne i kulturowe. W prezentowanym tekście podejmuję próbę poznania, co na temat edukacji i wychowania najmłodszych dzieci sądzą ich wychowawcy pracujący w jednym z warszawskich żłobków. Jakie formułują opinie, wyrażają poglądy i przekonania na temat dziecka, roli edukacji w jego rozwoju, roli ich samych, roli rodziców. Analiza tych kwestii wpisuje się w dyskusję nad jakością oferowanego przez instytucje wsparcia edukacyjnego.

Jakość edukacji, sądząc na podstawie analizy dostępnej literatury przedmiotu, zaprząta uwagę polskich badaczy i decydentów oświatowych, odpowiedzialnych za tworzenie systemu opieki, wychowania i edukacji, także dla dzieci najmłodszych, do trzeciego roku życia i w wieku przedszkolnym, od lat 80-tych XX w., podczas gdy w innych krajach, np. w Wielkiej Brytanii, Szwecji, Stanach Zjednoczonych już od lat 60-tych 1 .

Na podstawie różnorodnych znanych mi analiz badawczych i teoretycznych na temat konceptualizacji jakości edukacji, wychowania i opieki wyróżniłam dwie orientacje. Pierwsza orientacja opowiadająca się za stworzeniem uniwersalnych wskaźników jakości placówek dla najmłodszych dzieci, niezależnie od uwarunkowań społeczno-kulturowych, określana jest jako orientacja „obiektywistyczna” i globalistyczna. Dotychczasowe osiągnięcia teoretyczne i empiryczne pozwalają na, jak się wydaje, uzasadnione stwierdzenie, co najbardziej służy rozwojowi dziecka. W tej orientacji wyróżnić można dwa podejścia, strukturalne i procesualne. Podej-

\footnotetext{
1 Pionierskim przedsięwzięciem w tym obszarze były badania amerykańskie D. P. Weikarta: The Perry Preschool Program oraz późniejsze, prowadzone przez High/Scope Educational Research Foundation już w latach 60-tych ubiegłego wieku. Regulacje dotyczące tych zagadnień tworzone były w Polsce również wcześniej, ale nie były rozważane w kontekście jakości edukacji. Głównie dotyczyły tego, co określamy współcześnie jako kryteria jakości strukturalnej. Badania wskazują, że czynniki składające się na jakość strukturalną $\mathrm{w}$ istotny sposób korelują $\mathrm{z}$ jakością procesualną. Na przykład zróżnicowanie i liczba dostępnych dla dzieci materiałów koreluje z ich umiejętnościami poznawczymi (Montie, Xiang, Schweinhart 2007).
} 
ście strukturalne odpowiada na pytanie: jakie warunki powinny spełniać placówki w zakresie wyposażenia, wielkości grupy na jednego wychowawcę, powierzchni, wykształcenia i doskonalenia zawodowego personelu pracującego z dziećmi. Podejście procesualne dotyczy charakteru relacji między personelem i dzieckiem/dziećmi. Wychowawca odpowiadający za kryteria wysokiej jakości pracy stymuluje postęp w rozwoju i osiągnięciach edukacyjnych dzieci. Zarówno pierwsze, jak i drugie podejście wywołało zainteresowanie narzędziami pomiaru jakości oddziaływań instytucjonalnych. W USA powstały skale: ITERS, ECERS, CLASS (Infant, Toddler, Pre-K) ${ }^{2}$. Narzędzia powszechnie stosowane w Europie Zachodniej nie do końca odpowiadają na konteksty kulturowe innych krajów. Wykorzystywane w tych innych kontekstach wymagają ostrożności wrażliwej kulturowo i krytycznej refleksji. Ostatnie badania wskazują na potrzebę weryfikacji ich rzetelności i prawomocności w zastosowaniach poza ich kulturowo pierwotnym źródłem, ponieważ są one kalką, jak sądzą niektórzy, doświadczeń kulturowych, zbiorowej mądrości źródła pochodzenia (Ishimine, Tayler 2014) ${ }^{3}$.

Druga orientacja wpisuje się w paradygmat interpretatywny i dialogiczny. W niej definicja jakości ma naturę subiektywną, jej sens i znaczenie są konstruowane lokalnie, w procesie dialogu, debaty nad tym, co jest ważne, wartościowe i, w przeciwieństwie do tej pierwszej, uwzględnia uwarunkowania społeczno-kulturowe. Ten nurt rozważań nad jakością edukacji zyskał dużą popularność w europejskim środowisku naukowym dzięki książce: Beyond the Quality of Early Childhood Education. Postmodern Perspectives. Jej autorzy to Gunilla Dalhberg, Peter Moss i Alain Pence ${ }^{4}$. Chociaż dwie konceptualizacje jakości edukacji traktowane są jako rozłączne, mogą, jak sądzę, uzupełniać się, gdy przyjęta zostanie opcja wrażliwej interpretacji ich podstawowych założeń. Na przykład, owa subiektywna dialogiczna orientacja nadawania znaczenia pracy pedagogicznej może stanowić konsekwencje wcześniejszych analiz, prowadzonych w ramach orientacji obiektywistycznej lub odwrotnie - subiektywna tworzy materiał do konfrontacji z wynikami analiz prowadzonych na podstawie badań wykorzystujących naukowe, empirycznie potwierdzone przesłanki obiektywistyczne. Wtedy wychowawcy, nauczyciele konfrontują własne poglądy, przekonania na temat ich pracy pedagogicznej i potrzeb dzieci, obrazu dziecka, poczucia jego dobrostanu z doświadczeniami

\footnotetext{
2 ITERS - Infant Toddler Environment Rating Scale; ECERS - Early Childhood Environment Rating Scale; CLASS - Classroom Assessment Scoring System. Narzędzia te, od momentu opracowania ich wersji podstawowej, doczekały się wielu wersji zmodyfikowanych i rozszerzonych, np. ECERS-R; ECERS-E; standardy jakości wypracowane w NAEYC (National Association for Education of Young Children) w USA.

${ }^{3}$ W jednym z wątków badawczych w ramach projektu CARE analizowano kulturową „odpowiedniość” skali CLASS i uznano, że skala w niewystarczającym stopniu uwzględnia relacje między rówieśnikami (por.: Multiple case study in seven European countries regarding culture-sensitive classroom assessment, http // ecec-care.org/fileadmin/careproject/Publications/reports/CARE_WP2_D2_3_Multiple_Case_study_ FINAL_REPORT.pdf).

${ }^{4}$ Polskie tłumaczenie: Poza dyskursem jakości w instytucjach wczesnej edukacji i opieki. Języki oceny (Dahlberg, Moss, Pence 2013).
} 
ekspertów - teoretyków i praktyków z innych kultur. Wiedza ta może stanowić punkt wyjścia lub cel refleksji nad tym, jak wygląda praca pedagogiczna w danej placówce, co jest ważne, jakie zmiany mogłyby być zainicjowane, aby zaangażowanie praktyków w pracę pedagogiczną odpowiadało na oczekiwania dzieci, rodziców, społeczeństwa5 5 .

\section{Organizacja polskich badań w ramach projektu CARE}

Wyniki badań prezentowanych w tekście pochodzą z międzynarodowego projektu badawczego CARE (Curriculum and Quality Analysis and Impact Review of European Early Childhood Education and Care ${ }^{6}$ ), realizowanego w latach 2014-2016 na Wydziale Pedagogicznym Uniwersytetu Warszawskiego. Badania prowadzone przez konsorcjum badawcze składające się z 11 krajów europejskich zmierzały do wypracowania wrażliwych kulturowo propozycji wskaźników jakości edukacji dzieci uczęszczających do żłobka i przedszkola. Propozycje te sformułowano na podstawie złożonych, wielowątkowych badań, prowadzonych w paradygmacie jakościowym i ilościowym ${ }^{7}$.

W omawianych tutaj badaniach CARE przyjmuje się założenie, że definiowanie tego, co świadczy o wysokiej jakości edukacji nigdy nie jest neutralne, ale uwikłane w kontekst, w różne perspektywy, wizje dzieciństwa, teraz i w przyszłości oraz na dalszych etapach edukacji, w wieku dorosłym. Jest uzależnione od wielości czynników kulturowych, społecznych, osobistych, konstruujących ramy interpretatywne oglądu rzeczywistości „tu i teraz”, od wiedzy potocznej podmiotów odpowiedzialnych za ten proces (Klus-Stańska 2010). Nie traci się wtedy z oczu silnych stron dziecka i kontekstu jego rozwoju, tkwiących w kulturze i społeczeństwie, w jakim się wychowuje i rozwija, w przeszłości i wizjach przyszłości. Martin Woodehad (1998) pisze,

\footnotetext{
${ }^{5}$ Jeszcze inne podejście reprezentuje Lilian Katz, która proponuje ujmowanie jakości z kilku perspektyw: „z dołu”, dociekającej, co może służyć dziecku, którą można określić jako perspektywę poczucia dobrostanu dziecka; „z góry”, wskazującej cechy programu i warunki, w jakich ma być realizowany; „z zewnątrz”, określającej charakter stosunków między rodzicami i personelem: „Z wewnątrz”, definiującej stosunki wśród personelu, ale także między personelem i rodzicami, sponsorami, podmiotami zarządzającymi; „społeczną”, wyrażającą zainteresowanie jakością systemu przez społeczeństwo jako całość: por. L. Katz (2004). Inny badacz - Martin Woodhead - proponuje dynamiczne i kontekstowe ujęcie jakości (por.: M. Woodhead (1998)).

${ }^{6}$ Więcej na temat projektu CARE: http://ecec.care.org. Artykuł bazuje na wynikach badań prowadzonych w ramach projektu Unii Europejskiej, CARE (Curriculum Quality Analysis and Impact Review of European Early Childhood Education and Care, umowa 61338; PR7), na Wydziale Pedagogicznym Uniwersytetu Warszawskiego w latach 2014-2016. Realizacja projektu w Polsce była wspierana finansowo przez MNiSW w ramach środków finansowych na naukę (Praca naukowa finansowana ze środków finansowych na naukę w latach 2014-2016 przyznanych na realizację projektu międzynarodowego współfinansowanego).

7 Z finalnym dokumentem można już się zapoznać na stronie projektu: http://ecec-care.org
} 
Tradycje wychowania dzieci, powiązania rodzinne, a zwłaszcza przekonania rodziców kształtują wszystko, co we wczesnym dzieciństwie ma wartość, i rzutują na sposoby osiągania tej wartości. Jednocześnie specjaliści w dziedzinie psychologii rozwojowej wieku dziecięcego, nauczyciele i opiekunowie pozostają pod wpływem innych przekonań i nauki, której źródłem jest psychologia i teorie edukacyjne Zachodu (Woodehad 1998: 118-119).

Nie będę rozstrzygać tego, $\mathrm{w}$ jakim stopniu teorie konstruowane przez uczestników badań $\mathrm{w}$ projekcie CARE są zbieżne lub rozbieżne $\mathrm{z}$ wiedzą o rozwoju dziecka i jego edukacji, chociaż takie próby konfrontacji są podejmowane przez innych badaczy, ale chcę poznać, jakie one są. Jakie przekonania, oczekiwania na temat praktyk edukacyjnych wyrażają badani, co jest dla nich ważne, wartościowe, cenne, co, jak i kiedy powinno być w rozwoju dziecka uwzględniane. W celu zgromadzenia informacji zastosowano metodę wywiadu grupowego.

Istnieje wiele argumentów natury teoretycznej wskazujących, że osobiste teorie (implicit theories) na temat obrazu dziecka, dzieciństwa, roli instytucji w procesie edukacji mają związek z codziennymi zachowaniami opiekunów i dzieci w instytucji. Do takich hipotez przekonuje między innymi autor systemowej ekologicznej teorii rozwoju dziecka, który wskazuje na związki oczekiwań rozwojowych z praktykami edukacyjnymi opiekunów (van Bronfebrenner 1992), oraz autorzy koncepcji nisz rozwojowych, bazujący na badaniach antropologicznych (Super, Harkness 1992). Również Jerome Bruner pisał, że działania dorosłych pracujących z dziećmi w wieku szkolnym podyktowane są przekonaniami nauczycieli na temat umysłu dzieci (2006). Dahlberg, Moss i Pence (2000) zaproponowali klasyfikację podejść do edukacji dziecka na podstawie różnych nurtów i koncepcji pedagogicznych, tworzących fundamenty społecznego myślenia o dziecku. Badacze uważają, że koncepcje te są wyrazem swoistego metamyślenia o dziecku i jego edukacji. Formułowane głównie przez teorie i empirię określonego czasu historycznego i dominującej ideologii społecznej silnie zakorzeniają się w tzw. myśleniu społecznym, a więc także w poglądach osób pracujących z dziećmi i ich rodziców. W jakim stopniu mają one związek z codzienną praktyką pedagogiczną konkretnego wychowawcy lub nauczyciela, a także rodziców, to inna sprawa. Jak pisze Bruner (2006), na poglądy i osobiste teorie jednostki ma wpływ wiele czynników, którym w sposób niekontrolowany ulega, sprawiających, że wyrażane „tu i teraz” opinie niekoniecznie odzwierciedlane są $\mathrm{w}$ jej codziennych zachowaniach. Jednym słowem to zjawisko bardzo złożone i trudno uchwytne badawczo. Mimo tych wątpliwości istnieje wiele teoretycznych argumentów na rzecz badań nad osobistymi teoriami (i ich uwarunkowaniami) personelu pracującego z dziećmi w różnego typu instytucjach opieki i edukacji. Przyjmuję, że osobiste teorie to specyficzne narzędzia kulturowe, sposoby myślenia o edukacji, wychowaniu, przekazywane przez pokolenia, modyfikowane, konstruowane i rekonstruowane na podstawie wiedzy, tradycji, osobistych 
doświadczeń, bardziej subiektywnych czynników i bardziej sformalizowanych, zawartych w dokumentach regulujących pracę instytucji opieki i edukacji.

Jak wskazują najnowsze badania nad osobistymi teoriami rodziców (Super, Harkness 2004; 2009) i osobistymi teoriami nauczycieli (Tobin i in. 1989; Tobin, Arzubiaga, Adair 2014; Montovani, Bové 2010; Moran, Bové, Brookshire, Braga, Mantovani 2017), dorośli (rodzice i nauczyciele) wychowują i kształcą dzieci w różny sposób, ponieważ konstruują różne poglądy na temat dzieci, ich rozwoju i jego tempa, procesu uczenia się tego, co sprawia, że dziecko jest silne psychicznie, szczęśliwe, inteligentne, zdolne radzić sobie ze światem. Można także powołać się na inne badania wskazujące, że pewne cechy osób pracujących z dziećmi w instytucji mają związek z ich zachowaniami w stosunku do dzieci. Na przykład, oczekiwania wobec dzieci mają związek z charakterem strategii nauczania stosowanych przez nauczycieli (Charlesworth, Hart, Burts, Hernandez 1991; Stipek, Byler 1997). Deborah Stipek i Patricia Byler (1997) wykazały, że nauczyciele, którzy preferują strategię działania „skoncentrowaną na dziecku” (child-centered), wspierają bardziej rozwój umiejętności społecznych i niezależności, w przeciwieństwie do działań nauczycieli o przewadze strategii „skoncentrowanej na nauczycielu” (teacher centered), którzy w swoich działaniach w przedszkolu kładą nacisk na rozwój umiejętności akademickich i wiedzy faktograficznej. Wspomniane Stipek i Byler (1997) uważają także, że nauczyciele ulegają presji innych podmiotów (np.: rodziców, administracji), co wyhamowuje ich dążenia do realizacji własnych oczekiwań. Poczucie sprawstwa nauczyciela ma związek z wysokiej jakości oddziaływaniem, ukierunkowanym na rozwój czytania (Mashburn, Hamre, Pianta 2008), bliskie relacje z dziećmi i pozytywne wobec nich oczekiwania (Mashburn, Hamre, Downer, Pianta 2006).

Istnieje jeszcze jeden zasadniczy argument za celowością takich badań, który mógłby być również powodem dociekania rozstrzygnięć w wymiarze międzykulturowym, porównawczym. Charles Super i Barbara Harkness (2004) dostrzegają brak badań dotyczących problematyki teorii osobistych, weryfikujących ich hipotezę, że nie ma różnic w tym zakresie w krajach europejskich. Można przypuszczać, że procesy globalizacyjne, swoista „bliskość kulturowa”, te same korzenie cywilizacyjne (grecko-rzymskie, judaistyczne i chrześcijańskie) na takie hipotezy pozwalają. Relacjonowane w tym tekście badania w jakimś minimalnym sensie prowokują do takich porównań, czy rzeczywiście mamy do czynienia z podobieństwami w definiowaniu tego, co, jak i kiedy oferować dziecku, aby się uczyło i rozwijało, czy jednak nie. Przystępując do badań nad sensami nadawanymi rzeczywistości pedagogicznej przez nauczycieli, należy uwzględnić także tezę, że sensy owe w sposób pośredni, a nie finalny definiują jakość ich pracy pedagogicznej, ponieważ podstawowymi danymi o niej świadczącymi jest faktyczna, codzienna praca $\mathrm{z}$ dziećmi, a więc to, w jaki sposób interpretacje są przekładane na konkretne działanie. 


\section{Procedura badań i sposoby analizy ich rezultatów}

Proces badawczy w projekcie CARE dotyczył między innymi rozpoznania istniejących różnic i podobieństw w definiowaniu przez wychowawców i nauczycieli ${ }^{8}$ sensu pracy pedagogicznej z dziećmi zarówno w płaszczyźnie poziomej (czyli uczestniczących w badaniach w poszczególnych krajach), jak i pionowej (czyli ciągłości w ujęciu liniowym - dzieci w wieku do 3 roku życia, dzieci w wieku przedszkolnym), za pomocą pogłębionej analizy literatury, wywiadów z nimi, badań kwestionariuszowych (rodzice, opiekunowie dzieci i decydenci) oraz obserwacji dorosłych (wychowawcy w żłobku i nauczyciele w przedszkolu), ich interakcji z dziećmi. Ten ostatni wątek badawczy polegał na doborze w 7 krajach, biorących udział w tym zadaniu badawczym, celowego doboru 4 placówek, w których zaobserwowano tzw. „dobre praktyki” ${ }^{9}$. W nich nagrano filmy obrazujące codzienną pracę nauczycieli w przedszkolu i wychowawców w żłobku, interakcje wychowawców i nauczycieli z dziećmi podczas posiłku, zabawy swobodnej, zajęć dydaktycznych (organizowanych przez dorosłego w celu realizacji konkretnego celu dydaktycznego) i aktywności twórczej. Nagrania te stanowiły materiał do analizy jakości procesualnej za pomocą wymienionego wyżej narzędzia CLASS (Classroom Assessement Scoring System Toddler, Pre-K). Przeprowadzono również wywiady (indywidualne i grupowe), podczas których dyskutowano o wybranych elementach pracy przedstawionych na nagraniach ${ }^{10}$. Wywiady indywidualne przeprowadzono z wychowawcami oraz kierownikami żłobków, w których pracowali ci wychowawcy. Wywiad tworzył przestrzeń dla autorefleksji nad własnym działaniem. Pod koniec badań część badaczy uczestniczących w projekcie CARE stwierdziła, że interesującym zabiegiem badawczym mogą być wywiady grupowe z wychowawcami żłobka w konkretnym kraju na temat fragmentów nagranych filmów w innych krajach.

Analizowany w tym tekście wywiad stanowi zatem jedynie „odprysk” zakrojonego na szerszą skalę badania. Przeprowadzany był na podstawie fragmentów nagrań pracy wychowawców małych dzieci w instytucjach opieki i edukacji

\footnotetext{
${ }^{8}$ W wielu krajach europejskich osoby pracujące z dziećmi najmłodszymi to nauczyciele.

${ }^{9}$ Dyskusja na ten temat może stanowić treść innego tekstu, w tym momencie ograniczymy się do informacji, że dobierając żłobki i przedszkola do realizacji zadania badawczego, ograniczono się do opinii ekspertów.

${ }^{10}$ Zadanie to uzupełnione było o wnikliwą kwerendę źródeł wtórnych, takich jak: dokumenty regulujące funkcjonowanie systemu opieki, wychowania i edukacji, kształcenia wstępnego i doskonalenia zawodowego personelu dydaktycznego pracującego w danym kraju; kwerendę literatury światowej na temat badań nad szeroko pojętą jakością opieki, wychowania i edukacji instytucjonalnej (WP4), sondaż diagnostyczny na temat oczekiwań rodziców, wychowawców, nauczycieli (WP6), w tym pochodzących z grup ryzyka (rodziny imigranckie lub o niskim dochodzie), dotyczących rozwoju dzieci, funkcjonowania placówki, analizy rozwiązań w zakresie finansowania systemu ECEC (WP5) itd. Realizacja celu badawczego, jakim było wypracowanie rekomendacji dotyczących jakości pracy, polegała więc na szeroko zakrojonym i zróżnicowanym procesie korzystania ze źródeł i metod pozyskiwania danych, ich wielowarstwowej analizy.
} 
w Holandii, Portugalii i we Włoszech. Bodźcem wywołującym wypowiedzi badanych była prezentacja wybranych przez badaczy 3-7 minutowych fragmentów nagrań zrealizowanych w placówkach w tych trzech krajach ${ }^{11}$. Badanym $(\mathrm{N}=9$; wychowawcy, psycholog, kierownik żłobka) zadawano pytania na temat obejrzanych fragmentów filmu i pytania bardziej ogólne, ale dotyczące przedmiotu wywiadu (semi-ustrukturowany wywiad grupowy) ${ }^{12}$.

Zaproponowana metoda badania nawiązuje do analiz etnograficznych Josepha Tobina (1989), w których krótkie fragmenty filmów nagranych w instytucji służą jako bodźce wywołujące rozmowę między pracownikami instytucji w ramach wywiadu grupowego. W metodzie tej fragmenty prezentowane badanym nie są postrzegane jako dane z badań, ale jako inspiracja do wywołania wymiany opinii, poglądów. Ta wymiana nie tylko posłużyła badaczowi do realizacji założonego celu badawczego, ale również stała się bodźcem prowokującym uczestników do pogłębionej refleksji nad sensem ich pracy, zadawania dalszych pytań, otworzyła nowe perspektywy dla wymiany doświadczeń i wiedzy ${ }^{13}$.

\footnotetext{
11 To kraje, w których badacze z projektu CARE wyrazili zgodę na realizację tego zadania badawczego.

12 Wywiad taki przeprowadzono także w jednym z warszawskich przedszkoli. Chociaż ciekawe byłoby porównanie osobistych teorii wychowawców pracujących w żłobku z osobistymi teoriami nauczycieli przedszkolnych, to ten wątek nie będzie na razie tutaj analizowany. Zostanie zaprezentowany w następnym tekście, w którym postaram się odpowiedzieć na pytania: Czy istnieje między wychowawcami i nauczycielami jakaś spójność, koherencja w konstruowanych ramach interpretatywnych, wyrażanych werbalnie teoriach osobistych na temat opieki, wychowania i edukacji dziecka we wczesnym dzieciństwie, odkrywaniu sensu pracy pedagogicznej. Skoro rozwój dziecka nie jest procesem etapowym, pożądane byłoby, aby zasada ciągłości rozwoju odzwierciedlała się w przekonaniach osób pracujących z dziećmi w żłobkach i przedszkolach. Z tego względu nawet w sytuacji, gdy nie mamy wspólnej podstawy programowej dla tych dwóch najwcześniejszych etapów opieki, wychowania i edukacji instytucjonalnej, taka zgodność poglądów byłaby pożądana. Gwoli ścisłości należy zaznaczyć, że system opieki i edukacji podzielony jest między dwa ministerstwa, przedszkole jest pierwszym etapem systemu edukacji publicznej i podlega Ministerstwu Edukacji Narodowej, podczas gdy instytucje żłobkowe nie są częścią systemu edukacji, podlegają Ministerstwu Rodziny, Pracy i Polityki Społecznej. Nasze żłobki same, lokalnie wypracowują plany działania, w których uwzględniane są cele, treści i metody pracy. W wielu krajach w Europie te dwa etapy systemu są zintegrowane pod kątem koncepcji programowej, np. w krajach skandynawskich, w Danii, Norwegii. Czy zatem istnieje owa spójność poglądów na ten temat, czy nie? Jakie cele działania są ważne dla wychowawców, w żłobku, a jakie dla nauczycieli przedszkoli?

${ }^{13}$ Analiza nagranych wideoklipów to także źródło danych dla poznania różnych aspektów innowacyjnych podejść $\mathrm{w}$ zakresie doskonalenia zawodowego osób pracujących z dziećmi. To było jedno z ważnych zadań badawczych w ramach projektu CARE. Polegało ono na analizie indywidualnego przypadku „dobrych praktyk”. Aby zrealizować założony cel, posłużono się procedurą triangulacji pozyskiwania danych (Yin 2015), w tym przypadku danych jakościowych pochodzących z różnych źródeł informacji, i z wykorzystaniem różnych metod i narzędzi. Metoda analizy przypadku to przykład badań indywidualizujących. Każdy przypadek jest traktowany indywidualnie, generalizacja wyników badania jest ograniczona. Zawiera on progresywne postępowanie i wymaga zdefiniowania uwarunkowań historycznych, środowiskowych i innych cech kontekstowych. Wymaga, aby opinie, głosy wszystkich stron były uwzględnione. Zazwyczaj zawiera kolekcję różnych subiektywnych percepcji osób w danym przypadku. Zastosowanie takiego badania (Tobin i in. 1989, 2009), angażującego opiekunów i nauczycieli, kierowników i dyrektorów wybranych placówek jako podstawowych źródeł informacji, temu wymogowi czyni zadość. Chodziło o to, aby ich głos mógł być uwzględniony $\mathrm{w}$ analizach dotyczących jakości edukacji.
} 
0 wyborze danego nagrania i jego fragmentu zaprezentowanego uczestnikom badania decydował zespół ekspertów z krajów biorących udział w projekcie CARE, na podstawie wcześniejszych analiz tych nagrań, prowadzonych za pomocą narzędzia CLASS Toddler - jakości procesualnej pracy pedagogicznej.

Fragmenty prezentowane uczestnikom badania pochodzą z następujących na-

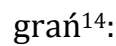

- Snailation (Nido-Bicocca, Włochy), wiedza przyrodnicza, mała grupa - fragment od 2' do 9'50";

- Building a Tower (Holandia), zabawa, mała grupa, pierwsze 6'35";

- Magic wands and disappearing Animals (Portugalia), cała grupa, aktywność z dominującą rolą wychowawcy (structured activity), od 3'30" do 8'45".

Uczestnicy wywiadu to osoby bezpośrednio zaangażowane jakby „od wewnątrz" w pracę instytucji, osoby kluczowe, a więc ich punkt widzenia powinien być uwzględniony $w$ analizach dotyczących jej jakości procesualnej, strukturalnej i odpowiada na postulaty charakteryzujące orientację dialogiczną ${ }^{15}$ badań. Te argumenty uzupełnia społeczne zapotrzebowanie na poznanie poglądów osób pracujących na co dzień z małymi dziećmi - jako znaczących ekspertów - na temat tego, co myślą o dziecku, jego edukacji, roli pełnionej w instytucji, jakie konstruują wizje edukacji, relacji dorosłego z dzieckiem lub dziećmi, jakie mają oczekiwania, przekonania wobec systemu opieki i edukacji.

W przewodniku do wywiadu znajdowały się pytania otwarte oraz pogłębiające je pytania zamknięte. Pytania dotyczyły sześciu obszarów pracy pedagogicznej wychowawcy małego dziecka ${ }^{16}$. Badacze przeprowadzający wywiad nie przestrzegali w pełni zarysowanej chronologii zadawania i treści pytań. Tworzyły one jednak ramy (prekoncepcję teoretyczną) zbierania danych, punkt wyjścia dla problematyzowania badanych wątków, w ramach których badani się poruszali. „Prekoncepcje” te nie były jednak podstawą dla automatycznego tworzenia kodów (Charmaz 2009: 92). Niektóre z nich były pomijane, zadawane w innym momencie lub pogłębiane i uszczegóławiane, gdy zaistniała taka potrzeba, na przykład nagła przerwa w dyskusji. Prowadzący wywiad starali się jak najrzadziej ingerować w jego dynamikę.

\footnotetext{
${ }^{14}$ Nagrania dostępne są na stronie projektu CARE w zakładce Video library (http://ecec-care.org).

${ }^{15}$ Kwerenda literatury polskiej na ten temat wskazuje, że problematyka jakości nabywanych przez dzieci doświadczeń rozwojowych i edukacyjnych w żłobkach, a więc jakości procesualnej, nie była, jak dotychczas, przedmiotem zainteresowania badaczy w Polsce. Wiele na jej temat się słyszy z ust polityków odpowiedzialnych za system opieki i edukacji najmłodszych. Pionierskim i chyba jak dotychczas jedynym badawczym dokonaniem, które wpisuje się w problematykę jakości pracy pedagogicznej, jest pozycja Lucyny Telki, w której autorka przedstawia swoistą innowację pedagogiczną towarzyszenia dziecku $w$ rozwoju w doskonaleniu zawodowym opiekunów pracujących z dziećmi w żłobkach łódzkich (Telka 2007; Telka 2012).

16 Przewodnik do wywiadu powstał w ramach projektu CARE, WP2, G. Pastori, S. Mantovani, P. Braga, V. Pagani (2015). Por. aneks w tym tekście.
} 


\section{Sposoby analizy otrzymanych danych i ich interpretacja}

$\mathrm{W}$ analizie danych z wywiadu inspirowałam się metodologią teorii ugruntowanej (tamże), aby odkryć „ramy interpretacyjne” dla postrzegania wycinka rzeczywistości pracy pedagogicznej przez wychowawców w żłobku (Alasuutari 1996). Przyjęłam założenie, że teorie osobiste „są rekonstrukcją sposobu, w jaki konstruujemy rzeczywistość, warunki społeczne i nas samych jako podmioty istniejące w tej rzeczywistości" (tamże: 382).

Pierwszym krokiem po przeprowadzeniu wywiadu był żmudny i czasochłonny proces jego transkrypcji ${ }^{17}$. W transkrypcji ograniczyłam się jedynie do zapisu oryginalnej treści i formy wypowiedzi. Inne dodatkowe cechy, towarzyszące sekwencji interakcji nie były uwzględniane ${ }^{18}$.

Następnie zgodnie z metodologią teorii ugruntowanej dokonano „kodowania wstępnego” - „wiersz po wierszu”, zadając sobie następujące pytania:

- Co można zbadać za pomocą tych danych?

- Co sugerują te dane, o czym świadczą?

- Z czyjego punktu widzenia?

- Na jakie kategorie teoretyczne wskazują zgromadzone dane (Charmaz 2009: 66).

Kodowanie to opatrywanie pewnych segmentów danych etykietami i analizowanie danych jakościowych $\mathrm{w}$ celu skonstruowania teorii ugruntowanej z owych danych (tamże: 8). Kodowanie wstępne polegało na przypisywaniu wyłonionym wypowiedziom, sekwencjom interakcji badanych określonych sensów sformułowanych w języku potocznym w formie rzeczowników odczasownikowych, aby zachować dynamikę analizowanych procesów. „Rzeczowniki odczasownikowe wywołują silne poczucie działania i sekwencji” (Glasser 1978, za: Charmaz 2009: 68). Niestety, czy to z braku dojrzałości metodologicznej badacza, czy oporu samej materii badanej nie zawsze udawało się dochować tej zasady. Starano się zachować otwartość na dane i możliwe ich interpretacje. Wielokrotne przeglądanie sekwencji interakcji badanych spowodowało liczne zmiany w nadawanym im sensom, czasami ich uzupełnienie, przesunięcia z jednej kategorii kodu wstępnego i skoncentrowanego do innej, wiele wahań dotyczących sensu i klasyfikacji do właściwego kodu wstępnego. Wykazało także wielość możliwych sensów, wyłaniających się za każdym razem, gdy przystępowałam do kolejnej analizy, wieloznaczność i dynamikę opisywanej materii z badań. Nie ustrzeżono się zapewne drobnych nieścisłości, subiektywizmu badacza analizującego dane.

\footnotetext{
17 Transkrypcja do wglądu dla zainteresowanych, kontakt: m.karwowska-st@uw.edu.pl

18 Wyczerpujących wskazówek na temat transkrypcji dyskursu dostarcza na przykład tekst Krzysztofa Koneckiego: Studia z metodologii badań jakościowych. Teoria ugruntowana (2000), a także tekst Tima Rapleya: Analiza konwersacji, dyskursu i dokumentów (2010), gdzie przedstawiono różne sposoby transkrypcji otrzymanych danych-sekwencji konwersacji. Przyznam, że jestem na początku drogi poznawania tych wyrafinowanych i bardzo dokładnych sposobów analizy dyskursu.
} 
Po tym etapie przystąpiłam do „kodowania skoncentrowanego” i pisania not - interpretacji danych w języku odkrywanych tez teoretycznych. Nie przyjmowałam żadnych założeń wstępnych, dotyczących kodowania danych, wyłaniały się one ze żmudnej i kilkukrotnej analizy przypisanych kodów wstępnych. Nie unikałam przypisywania tym samym sekwencjom wypowiedzi wychowawców różnych kodów szczegółowych i skoncentrowanych, pojawiają się one w wielu odsłonach, czasami powtórzenia te są tutaj przytaczane. „Kodowanie skoncentrowane jest drugim etapem kodowania. Kody te są bardziej ukierunkowane, wybiórcze i konceptualne niż kody powstałe w wyniku kodowania słowo po słowie, wiersz po wierszu..." (tamże: 79) i prowadzą do syntezy, ujęcia większej liczby (segmentów) danych. Powtórzenia, o których mowa, wskazują nie tylko na wielość możliwych interpretacji danych, ich wieloznaczność, także na intelektualne zmagania analizującego je badacza, pragnącego ukazać wielość możliwych interpretacji teoretycznych w nich zawartych i uniknięcie konceptualnego „szufladkowania” danych. Konsekwencją przyjętego założenia, nawet na etapie kodowania skoncentrowanego, był proces wielokrotnego powrotu do otrzymanych danych - sekwencji interakcji badanych. Mam wrażenie, że to proces niedokończony, więc pole do dalszych analiz i interpretacji dla innych badaczy. Zastanawiam się, czy procedura „sędziów kompetentnych" pozwoliłaby na wyłonienie ostatecznych kodów wstępnych i skoncentrowanych.

Kodowanie wstępne i skoncentrowane doprowadziło do zdefiniowania wielu kodów wstępnych i kilku syntetycznych kodów skoncentrowanych. Dla ścisłości i rzetelności tego procesu pracy z danymi trzeba dodać, że subkody były tworzone na podstawie analizy wielu wypowiedzi badanych. Następnie, w języku założeń teoretycznych (kodowanie teoretyczne) kody i relacje między nimi były interpretowane. W dalszej części artykułu przedstawiono efekt analizy danych.

\section{Koncepcja dziecka}

Z przeprowadzonej analizy sekwencji wypowiedzi wychowawców wyłania się obraz zbiorowej, ale zarazem „wspólnotowo osobistej teorii” (implicite theory) dziecka. To istota wymagająca troski, nadzoru i zapewnienia bezpieczeństwa fizycznego, mająca zróżnicowane potrzeby, zdolności i potrzebę niezależności. Dziecko jest aktywnym inicjatorem działania i uczenia się własnego i grupowego. Jest podmiotem $\mathrm{w}$ dwupodmiotowej interakcji z dorosłym, często pełni rolę nauczyciela, twórcy sytuacji edukacyjnych. Koncepcja dziecka, jaka wyłania się z wypowiedzi wychowawców, przełamuje w jakimś stopniu dominującą perspektywę dziecka jako „jednostki deficytowej” na rzecz dziecka „bogatego w potencjały, aktywnego twórcy kultury i własnej tożsamości" (Dahlberg, Moss, Pence 2000). Dzieci uczą się w różnym tempie, wiek wczesnego dzieciństwa to okres szczególnie podatny na przyswajanie dobrych nawyków, które owocują w latach późniejszych. 
Dzieci uczą się w sytuacjach dnia codziennego, spontanicznie i nieintencjonalnie, obserwując to, co się dookoła nich dzieje, zadając pytania. Uczą się w różnym tempie i dysponują różnymi zdolnościami. W sposób naturalny nastawione są na pochłanianie wiedzy, eksplorowanie świata. Przedstawione na nagraniach interakcje dzieci - dorosły z innych krajów są zdaniem badanych podobne do tego, co się dzieje w tym konkretnym „ich” żłobku, w którym pracują uczestnicy wywiadu. Podobieństwa w działaniach wychowawców wobec dzieci świadczyć mogą o zbliżonej koncepcji/obrazu dziecka mimo istniejących różnic kulturowych ${ }^{19}$.

\section{Cele uczenia się dzieci}

Cele te można zaliczyć do trzech głównych kategorii: sfery społecznej, np. szacunek dla innego, zasady bezpieczeństwa, zasady zachowania w grupie, samodzielność i odpowiedzialność; sfery samoobsługowej, np. nawyki higieniczne, oraz sfery umiejętności szkolnych, np. liczenie, rozpoznawanie kolorów, spostrzegawczość, klasyfikowanie. W tę sferę wychowawczynie włączyły również emocjonalność, dojrzałość emocjonalną dziecka. Uczenie się dzieci ma charakter liniowo-koncentryczny, tzn. doświadczenia z wczesnego dzieciństwa są fundamentem nabywania i poszerzania, pogłębiania $\mathrm{w}$ doświadczeniach późniejszych. Każda codzienna sytuacja jest ważna z perspektywy nabywania przez dzieci dyspozycji do uczenia się, takich jak cierpliwość, umiejętność czekania, samodzielność, umiejętność dzielenia się. Dyspozycje te można zaliczyć do komponentów samoregulacji poznawczej i emocjonalnej. Ta pierwsza polega na umiejętności kontrolowania własnych procesów poznawczych, ta druga - rozpoznawania, akceptowania i wyrażania w sposób akceptowany własnych emocji i uwzględniania perspektywy emocjonalnej w relacjach z innymi, ich stanów emocjonalnych i strategii działania. Bardzo wyraźnie uczestniczki wywiadu opowiedziały się za „kształtowaniem” u dzieci właściwych, kulturowo akceptowanych reguł życia w grupie, informowaniem, „czego wolno, a czego nie wolno robić”.

\section{Wychowawca „na posterunku”}

Zadaniem wychowawcy jest przede wszystkim obserwowanie postępu w rozwoju dzieci, wychwytywanie tworzonych przez nie sytuacji edukacyjnych, aby na ich bazie wzbogacać tworzone przez dzieci reprezentacje i pojęcia, stymulować ich myślenie, słowem postępować intersubiektywnie zgodnie z zasadą SST (Sustained Shared Teaching) - podzielania i podtrzymywania myślenia dzieci i dialogicznego

\footnotetext{
${ }^{19}$ Coraz trudniej odkryć to, co jest lokalne w morzu imperatywu globalizacji odnoszącej się do edukacji. Postulat Super i Harkness (2004) o badania europejskie nad teoriami osobistymi personelu pracującego z dziećmi nadal jest aktualny.
} 
nauczania (dialogical teaching). Takie sytuacje mają miejsce w trakcie zabawy, gdy dzieci są czymś spontanicznie zainteresowane. Zajęcia celowo organizowane nie są główną domeną działania pedagogicznego wychowawców biorących udział w wywiadzie ${ }^{20}$. Sytuacje okazjonalne, często wywoływane przez zainteresowania dzieci, tworzą fundament, inspirację dla dalszych działań wychowawcy ${ }^{21}$. Według wychowawców naśladownictwo, obserwowanie dorosłego, modelowanie to główne strategie uczenia się dzieci. Nie należy przyśpieszać rozwoju dziecka, ale tworzyć sytuacje, dzięki którym dziecko w pewnym momencie włączy się w proponowane działania. Odwołując się do dychotomii w pracy pedagogicznej: „skoncentrowania na dziecku” lub „na nauczycielu”, wydaje się, że ta pierwsza opcja przeważa w interakcji z dzieckiem/dziećmi. W pewnym sensie za jej dominację, którą odbieram pozytywnie, odpowiada brak jakiegokolwiek dokumentu w postaci podstawy programowej, sterującego działaniami wychowawców w żłobku.

\section{Organizacja pracy w żłobku}

Kilkakrotnie w dyskusji pojawiał się wątek liczby dzieci pod opieką wychowawcy (nauczyciela). To znaczy, że to kryterium jakości strukturalnej jest ważne dla wychowawców. Na nagraniach przedstawione były sytuacje pracy wychowawcy z małą grupą (5-6 dzieci). Zdaniem osób biorących udział w wywiadzie to bardzo korzystna sytuacja, zapewniająca skuteczny nadzór nad dziećmi, brak problemów z kierowaniem ich zachowaniem i dyscyplinowaniem, zapewnieniem im bezpieczeństwa, a przede wszystkim spokojną i wrażliwą uwagę na sygnały przekazywane przez dzieci. Czas do dyspozycji wychowawcy dzielony jest na zabawę i na zajęcia zorganizowane, dzięki temu dzieci nabywają doświadczenia w zakresie niezależności i samodzielności, gdy podejmują działania z własnej inicjatywy. Gdy zajęcia grupowe organizuje dorosły, dzieci uczą się reguł funkcjonowania w grupie i podporządkowania własnej aktywności temu, co proponuje wychowawca.

\section{Rola instytucji (żłobek-przedszkole-szkoła)}

Uczestnicy dyskusji podkreślali zbieżność stylu pracy wychowawców w żłobku z pracą w przedszkolu, w którym podobnie jak w żłobku dominuje zabawa jako główna aktywność dzieci i ich linia rozwoju. Praca pedagogiczna w żłobku to podstawa dla późniejszych wzbogacających i poszerzających wiedzę i umiejętności

\footnotetext{
${ }^{20}$ Jedna z kolejnych wersji tekstu została przekazana biorącym udział w wywiadzie, którzy zapewnili mnie, że nie jest tak, że w pracy z dziećmi ograniczają się do nieintencjonalnych sytuacji edukacyjnych. Pracownicy żłobka opracowują tygodniowe, miesięczne plany zajęć, które są systematycznie realizowane.

${ }^{21}$ Zabawa dzieci wymieniana była bardziej jako aktywność inicjująca działania edukacyjne dorosłego, a nie jako forma uczenia się per se. Można wnioskować, że mamy w tym przypadku do czynienia z relacją wertykalną (dorosły - dziecko/dzieci) częściej, a nie horyzontalną (dziecko - dzieci).
} 
dzieci działań przedszkola i szkoły. Zatem można przypuszczać, że w stanowisku tym odzwierciedla się idea ciągłości rozwojowej. Podkreślano prorozwojowe znaczenie przedszkola stymulującego i kompensującego braki w zakresie wiedzy i umiejętności dzieci nieuczęszczających do żłobka. Właściwa stymulacja rozwojowa $\mathrm{w}$ tej instytucji jest $\mathrm{w}$ stanie sprawić, że te dzieci nie tylko dogonią dzieci uczęszczające do żłobka, ale nawet mogą je wyprzedzić w pewnych umiejętnościach i kompetencjach. Uczestniczki badań nie dostrzegają negatywnych konsekwencji zmiany jednej instytucji na drugą, czyli przejścia dziecka ze żłobka do przedszkola. Dzieci są na to gotowe emocjonalnie i poznawczo. Inaczej przedstawia się kwestia relacji doświadczeń nabywanych przez dzieci w żłobku do oczekiwań szkoły. Tutaj ich opinie były bardziej ostrożne i wyważone. Niemniej żłobek to tworzenie podstaw dla umiejętności, koncentracji uwagi, przyzwyczajanie do życia w grupie, samodzielności, samokontroli emocjonalnej, które procentują również w dalszej karierze edukacyjnej dziecka. Podkreślono zatem, że uczenie to długi proces, trwający całe życie. Zwrócono jednakże uwagę na różnice w procesie i efektach rozwoju u dzieci trafiających do przedszkola ze żłobka i tych z domu rodzinnego, na korzyść tych pierwszych.

\section{Żłobek i rodzice}

Wychowawcy wyróżnili dwie kategorie postaw rodziców dzieci uczęszczających do placówki: postawę zainteresowania dzieckiem przejawiającą się na przykład wzajemnym informowaniem o sukcesach rozwojowych dziecka i próbach wzajemnego dopasowania oddziaływań stosowanych w jednym ze środowisk (rodzinnym lub żłobkowym) do drugiego, a więc koherencję w stylach działania, wzajemne uczestniczenie w procesie wychowania i edukacji. Druga postawa oznacza brak zainteresowania dzieckiem i traktowanie żłobka jako przechowalni, podczas gdy rodzice oddają się swoim obowiązkom. Jest to swoista jednokierunkowa, przedmiotowa i klientystyczna relacja. Wskazywano także na trudności w komunikowaniu się z rodzicami, gdy osiągnięcia rozwojowe dziecka nie są wystarczające. Niektórzy rodzice takich informacji nie chcą słyszeć, ponieważ wywołują one dysonans w ich obrazie dziecka i formułowanych przez nich wobec niego oczekiwaniach. Niezależnie od nastawienia rodziców wychowawcy starają się informować rodziców o osiągnięciach lub słabszych stronach ich dziecka. Wielu rodziców jest zaskoczonych postępem dzieci w rozwoju. Oczekiwania rodziców wobec instytucji są więc zróżnicowane i te zróżnicowania stara się ona uwzględniać.

\section{Rozwój zawodowy personelu pracującego z dziećmi}

W tej kwestii wskazano na dwie możliwości. Pierwsza polega na organizowaniu systematycznych spotkań przez kierownictwo placówki. Można tę formę określić jako system wewnętrznego doskonalenia zawodowego. Druga forma doskonalenia 
polega na doraźnych, w miarę potrzeb, kontaktach z ekspertami z zewnątrz, np. z psychologiem, logopedą, gdy wychowawcy nie są w stanie sami zaradzić jakieś krytycznej dla nich sytuacji ${ }^{22}$.

\section{Podsumowanie}

Żłobek to miejsce spotkania zróżnicowanych interesów, oczekiwań, aktorów, ról społecznych, miejsce, gdzie szczególnie silnie opieka i wychowanie stykają się z edukacją, gdzie świat rodziców, dzieci, domu rodzinnego po raz pierwszy zderza się z potrzebami pracujących (na ogół) matek, ich aspiracjami zawodowymi, oczekiwaniami społeczeństwa dotyczącymi dobrze rokujących w przyszłości dorosłych. Spojrzałam na tę instytucję z perspektywy potocznych, osobistych teorii wychowawców, przyjmując założenie, że dzięki ich wypowiedziom uda się uchwycić w procesie ko-konstrukcji znaczenia, jakie jej nadają „ramy interpretatywne” rzeczywistości, w jakiej się znajdują i jaką wspólnie tworzą (parafraza za: Tobin, Hsueh, Karasawa 2009: 2).

Jeszcze raz należy podkreślić ograniczenia metodologiczne prowadzonych poszukiwań badawczych i dokonanych interpretacji. Skonstruowana „wspólnotowa teoria osobista” to efekt refleksji grupy odważnych i zainteresowanych udziałem w badaniu wychowawców z jednego warszawskiego żłobka. Zasięg prowadzonych interpretacji jest więc bardzo ograniczony do tego konkretnego środowiska. Jak w każdym tego typu badaniu według paradygmatu jakościowego obarczone jest ono subiektywnymi „odczytaniami” przez badacza „sensów” wypowiedzi uczestników badania. Ich refleksja, wymiana poglądów, doświadczeń, wiedzy, umiejętności daje podstawy do stwierdzenia, że mieliśmy w tym przypadku do czynienia z uczeniem się sytuacyjnym (situated learning), którego cechami charakterystycznymi są refleksyjna, krytyczna wymiana między zaangażowanymi i odpowiedzial-

\footnotetext{
${ }^{22}$ Inne formy doskonalenia zawodowego, np. rozwiązania systemowe, których w odniesieniu do tej grupy zawodowej nie ma w Polsce, nie były uwzględniane. Jak świadczą badania prowadzone w projekcie CARE, odwołujące się do praktyki, systematyczne doskonalenie zawodowe jest najbardziej skuteczne w sensie wzbogacania, tworzenia bardziej adekwatnego do potrzeb dziecka warsztatu pracy nauczyciela. Być może wymienione formy takiego wsparcia profesjonalnego wystarczają wychowawcom. Zważywszy na trudności związane ze zmianą w teoriach osobistych (implicit theories) wychowawców, a co więcej trudności ich przełożenia na codzienną praktykę, gdy utarte modele działania się nie sprawdzają, te dwie formy doskonalenia wewnętrznego wydają się słusznie podkreślane przez wychowawców. Jak pisze J. J. Tobin (2009), „wyzwaniem dla każdego przedszkola jest w każdym kraju utrzymanie prawidłowej, właściwej równowagi między kontynuacją a zmianą" (tamże: 2). Być może tę równowagę $\mathrm{w}$ modelach pracy pedagogicznej badanych wychowawców zapewniają takie właśnie formy doskonalenia zawodowego. Bernard Spodek (1987) uważał, że praktyczna wiedza nauczyciela, bardziej niż teorie rozwoju i uczenia, determinuje jego decyzje pedagogiczne, co by potwierdzało, w pewnym sensie, to przywiązanie intelektualne osób pracujących z dziećmi do ich doświadczeń praktycznych i brak teoretycznych odniesień w analizowanych wypowiedziach.
} 
nymi za dzieci profesjonalistami, poszukującymi własnych, osobistych konceptualizacji dla pracy pedagogicznej, jej celów, roli w rozwoju i edukacji dzieci.

Na koniec należy podkreślić fakt ukierunkowania toku wywiadu prowadzonego wśród wychowawców przez tematykę zadawanych przez badaczy pytań. Być może udałoby się ich uniknąć, gdyby w badaniach wykorzystano wywiad narracyjny, swobodną wypowiedź badanych.

\section{Bibliografia}

Adair J., Pastori G. (2011) Developing Qualitative Coding Frameworks for Educational Research: Immigration, Education and the Children Crossing Borders project, „International Journal of Research and Method in Education", 34 (1), s. 31-47.

Alasuutari P. (1996) Theorizing in qualitative research; A cultural studies perspective, "Qualitative Inquiry”, 2, s. 371-384.

Alexander R. (2008) Culture, dialogue and learning: Notes on an emerging pedagogy w: Exploring talk in school, N. Mercer, S. Hodgkinson (red.), London, Sage, s. 91-114.

Alexander R. (2005) CULTURE, DIALOGUE AND LEARNING: NOTES ON AN EMERGING PEDAGOGY. Education, Culture and Cognition: intervening for growth, International Association for Cognitive Education and Psychology (IACEP) 10th International Conference, University of Durham, UK, 10-14 July 2005, Keynote: 12 July 2005.

Bredekamp S., Copple C. (red.) (1997) Developmentally appropriate practice in early childhood programs serving children from birth through age 8, Revised Edition, Washington, DC, National Association for the Education of Young Children.

Charmaz K. (2009) Teoria ugruntowana. Praktyczny przewodnik po analizie jakościowej, tłum. B. Komorowska, Warszawa, Wydawnictwo Naukowe PWN.

Dahlberg G., Moss P., Pence A. (2000) Beyond the Quality of Early Childhood Education. Postmodern Perspectives, London, Routledge Falmer.

Dahlberg G., Moss P., Pence A. (2013) Poza dyskursem jakości w instytucjach wczesnej edukacji i opieki. Języki oceny, tłum. K. Gawlicz, DSW, Wrocław.

Glaser B. (1978) Theoretical sensitivity, Mill Valley, CA, The Sociology Press.

Harkness B., Super C. M. (2004) Themes and Variations: Parental Ethnotheories in Western Cultures w: Parental Beliefs, Parenting, and Child Development in CrossCultural Perspective, K. Rubin (red.), New York, Psychology Press. 
Harkness B. i in. (2010) Parental Ethnotheories Of Children's Learning w: The Anthropology Of Learning In Childhood, D. G. Lanch, F. Gaskins (red.), Lanham, MD, Alta-Mira Press, s. 65-81.

Harms T., Clifford R. M., Cryer D. (1997) Early Childhood Environment Rating Scale, Revised Edition, New York, London, Teacher College Press, Columbia University.

Ishimine K., Tayler C. (2014) Assessing Quality in Early Childhood Education and Care, „European Journal of Education”, 49 (2), s. 272-290.

Justice L. M., Mashburn A., Hamre B., Pianta R. (2008) Quality of Language and Literacy Instruction in Preschool Classrooms Serving At-Risk Pupils, Early Child Res Q.Mar, 23 (1), s. 51-68.

Katz L. (2004) Wielorakie spojrzenie na jakość nauczania poczq̨tkowego w: Nigdy nie jest za wcześnie - rozwój i edukacja małych dzieci, T. Ogrodzińska (red.), Warszawa, Fundacja Rozwoju Dzieci im. Jana Amosa Komeńskiego.

Klus-Stańska D. (2010) Dydaktyka wobec chaosu pojęć i zdarzeń, Warszawa, Wydawnictwo Akademickie „Żak”.

Konecki K. (2000) Studia z metodologii badań jakościowych. Teoria ugruntowana, Warszawa, Wydawnictwo Naukowe PWN.

La Paro K., Hamre B., Pianta R. (2012) The Classroom Assessment Scoring System (CLASS), Manual, Toddlers, Baltimore, Brookes.

Mashburn A. J., Hamre B. K., Downer J. T., Pianta R. C. (2006) Teacher and classroom characteristics associated with teachers' ratings of prekindergartners' relationships and behaviors, „Journal of Psychoeducational Assessement”, 4 (24), s. 367-380.

Montie J., Xiang Z., Schweinhart L. J. (2007) The role of preschool experience in children's development, High Scope Press, Press.

Moran M. J., Bové C., Brookshire R., Braga P., Mantovani S. (April 2017) Learning from each other: The design and implementation of a cross-cultural research and professional development model in Italian and US toddler classrooms, „Teacher and Teacher Education", 63, s. 1-11.

Moran M., Mantovani S., Braga P., Bove C., Brookshire R. (w druku) Learning from Each Other: Cross-cultural Research on Italian and U.S., Early Childhood Professional Development and Toddler Teacher Practice.

Nowicka M. (2016) Wartości w świecie dziecka w przekonaniach dorosłych - przyszłych nauczycieli, „Problemy Wczesnej Edukacji”, 2 (33), s. 152-165. 
Pastori G., Mantovani S., Braga P., Pagani V. (2015) Manual case study, qualitative and cultural study and analysis (mps.).

Pianta R. C., La Paro K. M., Hamre B. K. (2008) The Classroom Assessment Scoring System (CLASS), Manual, Pre-K, Baltimore, Brookes.

Rapley T. (2010) Analiza konwersacji, dyskursu i dokumentów, tłum. A. Gasior-Niemiec, Warszawa, Wydawnictwo Naukowe PWN.

Rogoff B. (2008) Observing sociocultural activity on three planes: Participatory appropriation, guided participation and apprenticeship w: Pedagogy and practice: Culture and identities, P. Murphy, K. Hall, J. Soler (red.), Los Angeles, Sage, s. 58-74.

Spodek B. (1987) Thought processes underlying preschool teachers' classroom decisions, „Early Child Development and Care”, 29 (2), s. 197-208.

Stipek D., Byler P. (1997) Early childhood education teachers: Do they practice what they preach?, „Early Childhood Research Quarterly”, 12 (3), s. 305-325.

Telka L. (2007) Przekształcanie przestrzeni społecznej placówki. Studium społeczno-pedagogiczne na przykładzie żłobków, Łódź, Wydawnictwo Uniwersytetu Łódzkiego.

Telka L. (2012) Wspieranie autonomii małego dziecka w placówce - wychowanek i wychowawca, „Problemy Współczesnej Edukacji”, nr 4 (19), s. 6-20.

Tobin J. J., Arzubiaga A., Adair J. (2014) Children crossing borders. Immigrant parents and teachers perspectives on preschool, Los Angeles, Sage.

Tobin J. J., Hsueh Y., Karasawa M. (2009) Preschool in Three Cultures. Revisited, Chicago, University of Chicago Press.

Tobin J. J., Mantovani S., Bové C. (2010) Methodological Issues in Video Based Research on Immigrant Children and Parents in Early Childhood Settings, Phenomenology and Human Research Today, Zeta Books, s. 204-225.

Tobin J. J., Wu D., Davidson D. (1989) Preschool in Three Cultures: Japan, China, and the United States, New Haeven, C.T., Yale University Press.

Woodhead M. (1998) Dążenie ku tęczy. Poszukiwanie standardów jakości edukacji, Warszawa, tłum. M. Rączkowska, red. nauk. M. Karkowska-Struczyk, Wydawnictwo Akademickie „Żak”.

Yin R. (2015) Studium przypadku w badaniach naukowych, tłum. J. Gilewicz, Wydawnictwo Uniwersytetu Jagiellońskiego, Kraków. 


\section{Aneks}

Przewodnik wywiadu grupowego $\mathrm{z}$ wychowawcami żłobka w konkretnym kraju na temat fragmentów nagranych filmów w innych krajach.

- Obszar pierwszy zawierał następujące pytania: Jakie elementy waszej pracy w obejrzanym filmie są podobne, a jakie różne? Jak podobał się obejrzany fragment filmu? Czy było w nim coś, co zwróciło pań uwagę? Czy było w nim coś, co ma miejsce również $\mathrm{w}$ tej placówce, w której panie pracują? Co wydaje się paniom podobne lub różne, ewentualnie, jakie są główne różnice?

- Obszar drugi zawierał pytania: Czego dzieci się uczą, czego powinny się uczyć w tym wieku? Czego dzieci nauczyły się w tych dwóch sytuacjach? Proszę powiedzieć, do którego fragmentu filmu panie się odnoszą? Czy sądzą panie, że wspierają uczenie się dzieci w podobny/inny sposób? Proszę o podanie przykładów konkretnych sytuacji, w których ma to miejsce? Jak panie sądzą, czego dzieci w tym wieku powinny się uczyć $\mathrm{w}$ takich placówkach jak wasza? Jaki jest cel uczenia się dzieci w tym wieku? Czy rodzice formułują jakieś oczekiwania wobec uczenia się dzieci? Czy nauczyciele przedszkolni, szkolni formułują takie oczekiwania? Jakie one są?

- Obszar trzeci zawierał pytania: Jak wychowawcy/nauczyciele powinni wspierać uczenie się dzieci? Jak nauczyciele wspierali uczenie się dzieci na filmie? Co jest inne, a co podobne do tego, co się dzieje w waszej placówce? Jak panie wspierają uczenie się dzieci? Jaka jest wasza rola w uczeniu się dzieci? Jakie działania im proponujecie? Kiedy najczęściej wspierają panie uczenie się dzieci?

- Obszar czwarty zawierał pytania: Jak dokumentować, jak oceniać uczenie się dzieci? Jak obserwujecie uczenie się dzieci? Jakie metody, narzędzia panie stosują? Jak panie oceniają osiągnięcia dzieci? Czy rodzice domagają się tego typu informacji? Kiedy, w jakich sytuacjach? Za pomocą jakiej dokumentacji? Co generalnie sądzą panie o ocenianiu, ewaluacji, dokumentowaniu dokonań dzieci?

- Obszar piąty zawierał pytania: Jak pracować z dziećmi, uwzględniając ich indywidualne i specjalne potrzeby? Czy pracują panie z dziećmi ze środowisk imigranckich lub o niskim statusie materialnym? Na co zwracacie uwagę, pracując z nimi? Proszę podać przykłady. Czy macie dzieci z jakąś niepełnosprawnością, jak sobie $\mathrm{z}$ nimi radzicie?

- Obszar szósty zawierał pytania: Co sądzicie o gotowości przedszkolnej/szkolnej? Czy wszystkie dzieci opuszczające placówkę są gotowe, aby podjąć edukację przedszkolną/szkolną? Co ogólnie sądzicie o gotowości przedszkolnej, szkolnej dziecka? Czy zwracacie uwagę na specyficzne cele rozwojowe (główne przekonania, wątpliwości, napięcia, z którymi trzeba sobie poradzić - szczególnie te dotyczące gotowości przedszkolnej/szkolnej, twardych i miękkich umiejętności)? Czy formułowane są w tym kontekście jakieś wymagania ze strony rodziców, nauczycieli z przedszkola/szkoły? 